\title{
Three Problems Noticeable for Patriotism Teaching
}

\author{
Wenping Ma \\ Department of Ideology and Politics Teaching and Research \\ Dalian Jiaotong University \\ Dalian, China
}

\begin{abstract}
Loving the country" is the core of individual cultivation and practice of socialist core values, in the teaching of "inherit patriotic tradition and carry forward China spirits" given in Chapter II of Moral Education and Fundamentals of Law course for college students in China, more analysis shall be conducted on the multiple meanings of loving the country, avoid students from rejecting or resisting the this word, clarify theoretical problems such as "Does loving the country go without socialism? And so on, with the full understanding of students' patriotic expression and characteristics, this article is expected to help the students set and practice the patriotic values.
\end{abstract}

Keywords-Moral Education and Law Bases; patriotism; teaching

\section{INTRODUCTION}

The 18th CPC National Congress held in 2012 raised that the patriotism shall be the core of individual cultivation and practice of socialist core values, plus, it stresses the unification of patriotism and socialism, deeply discussing important issues relative to patriotism in the new stage. May 2013, president Xi Jinping presented the youth his ardent hope "dedicated to learning, active in labor and love the motherland", which set a direction for the healthy growth of contemporary youth. Therefore, how to integrate the patriotism spirit described in the 18th national congress, $\mathrm{Xi}$ Jinping's hope to the patriotism education of college students, and bring the patriotism education to the height of theory and practice and enable the students actively cultivate and practice the socialist patriotism values have become an important teaching problems for teachers of Moral Education and Law Bases to solve.

\section{CORRECTLY UNDERSTAND THE MULTIPLE MEANINGS OF PATRIOTISM}

What is love? Love is an internal drive for social interaction and individual development, what is shown is not only a feeling, a behavior but also a behavioral pattern and obligation. [1] What a country is? Country refers to motherland. The word motherland has rich contents, it is an integration of nature, politics, economy, culture and history and a social community for survival of human being which consists of state lands, people and state apparatus in a certain stage of history with a certain region. Anyone who survives

This paper is the Teaching Practice Mode Research (DJDJG201555) Staged Result of Dalian Jiaotong University Teaching Reform Topic "Moral Education and Fundamentals of Law" in 2015 in the society has to get material conditions for survival and development and create a home for mental comfort, when the political, cultural and social environments that the country offers can meet the people in survival, development and perfection, it will bring active effect, patriotism is a cognition of the people to the motherland value namely the relation between individuals and motherland and corresponding behaviors.

"Loving the country" contains rich meaning, and the patriotism we speak of frequently is just a part of it on a level.

Level I, the "loving the country" used in social practice refers to a system which consist of simple patriotic feelings and patriotic behaviors, which is essential.

Level II, the "loving the country" in concept is a rational system which rises out of the specific feeling, thoughts and behaviors of loving the country, it not only shows a specific patriotic feeling, ideas or behaviors, but also a rational cognition about the relations between individuals and motherland. The loving the country in thought refers to patriotism, belonging to superstructure and ideology, it is a theoretical system which is determined by and serves the certain economic foundation. Within routine social life, generally the patriotism works as a rule and standard to restrain the thoughts and behaviors of the people such as political principle, moral and so on. As a rational understanding or concept, the patriotism is much steadier compared to simple patriotic feeling.

Level III, as a value orientation, "loving my country" means that the people of a country should exert what they have had for the prosperity of the country and nation, which is devotion but not a simple patriotic feeing, affective impulse or unrealistic extremist opinions or behaviors. Actually it is a firm sense of national pride, self confidence and self respect and a cohesion hidden in the heart of everyone. The cohesion is mixed with feeling, faith, mission and responsibility, forming an internal psychological mechanism for the survival and development of Chinese nation, and a spiritual backbone and soul of the nation that last forever. "Loving my country", belonging to spiritual culture, is beyond the patriotism as political principle and moral standard, which stresses to strengthen the awareness of the nation, union, unexpected development and responsibility, and brings a powerful spiritual power to the national cohesion.[2] 


\section{Clarify ThreE TheORETICAL PROBlems}

A. Patriotism Is the Strongest Feeling to the Motherland that Has Been Accumulated for Thousands of Years, Is It True An Expression of Lenin?

In my opinion, it was wrongly translated, in the Vol. 28, Ver. 1 of Collected Works of Lenin (1956) and Vol. 3, Ver. 1 of Collected Works of Lenin (1960), it was wrongly translated into "Patriotism is the strongest feeling to the motherland that has been accumulated for thousands of years". The phrase has spread around the world as an incisive summary of patriotism by Lenin, proletariat soldiers that Lenin or Marx expressed were not so called patriots but "world citizen" who get rid of all kinds of prejudices and own distinct proletarian consciousness and international vision[3]. The "patriotism is an extremely strong feeling formed due to the separation between motherlands that last thousands of years" held by the petty bourgeoisie was criticized by Lenin[4]. This kind of patriotism is an outdated and narrow one. It is true that Lenin would not criticize or deny the strong feeling of the people to the motherland at random. For the patriotic just war of the people against the colonial rules to get rid of colony and semi-colony, Lenin not only understood it completely but also gave great support. [5]Nowadays, in the course of reform, opening-up and modern construction, to advocate and carry out the spirit of patriotism will have great significance in practice and theoretical value, which is proper and necessary completely. In the era of globalization, the patriotism must be kept open but not a nationalism which is closed, blind to reject foreign things or narcissistic. The opening of patriotism must be inclusive. What a country needs in the era is not only powerful strength but also confidence and inclusion.

\section{B. Does Loving Country Go Well without Patriotism}

What is a country? "Country is a tool that is used by one class to oppress the other and through which one class is completely controlled by the other'[6]. This is a summary made by Lenin over the country concepts of Marx and Engels, which is the most complete and correct. A country is a political community for the people who live there and a total representative for the people and the whole national in pursuit of material benefits and spirits. With a country given, the people and the nation can survive and develop. Nowadays, local wars still take place one after another and the world politics and military situations change quickly, the security, living and development of each Chinese and the whole Chinese nation and the heritance and promotion of national dignity, tradition and spirits all be closely connected with the changes of the country as a political community. Patriotism goes with establishment of a country and develops with it as well. And the development of each person is closely related to the development and progress of the country, loving motherland requires being concerned about the prospect and fate of the country, and placing the benefits of the country and people beyond others, and contribute what we can for the independence, prosperity as well as the liberation and happiness of the people. Therefore, our patriotism can be only correctly exerted and expressed on the basis of loving my country and the core value

\section{Does Loving the Country Go Without Socialism}

Persistence and construction of socialism shall be what up-to-date patriotism in China should have, generally the patriotism is reflected through loyalty to motherland, loving the mountains, rivers, people, culture and language of motherland and restrict what we do in accordance with excellent tradition and ideology. However, we should not oppose loving the country to socialism, and the internal connection between patriotism and socialism is "Socialism is the only way for China to develop", which is an unshakable historical conclusion that Chinese people have drawn from the development. Someone ever said he or she still loves the country even not loving socialism, to which, Deng Xiaoping severely denounced: "Is motherland abstract? What will you do if you do not love the socialist country led by the CPC'[7]? Therefore, currently loving the country, patriotism and socialism are unified in nature. And the trend of the patriotism to socialism is a selection of the development, and the patriots are automatically becoming a drive for the socialist construction and national unity and make contributions to the modern socialist construction.

\section{CORRECTLY UNDERSTAND STUDENTS' PATRIOTIC ACTS AND CHARACTERISTICS IN THE NEW STAGE}

The students who were born in the 1980s or 1990s are often scolded as a generation of collapse, a generation of lack of responsibility, a generation of ignorance, a generation of selfishness and a generation of treason due to excessive pursuit of personally, self, freedom, indifference and lack of emotion. However, in the face of state sovereignty, national dignity, severe natural disasters especially the accidents in 2008, the students had their images changed, whose patriotic enthusiasm make the people really feel the students' feeling to the country and the nation. The rising group phenomena such as devotion to village official, devotion to teaching, devotion to work in the west region, devotion to being volunteers and so on have reflected that contemporary students' value of the era for the country and the senses of social responsibility and mission to devotion to the motherland through actions. Therefore, spoken as a whole, the patriotic quality of contemporary students is optimistic in the country, who show their pursuit of staying and developing with motherland, devoting themselves to practice and contributing to the society through real actions. Yet, there are still some behaviors of students which are worrying.

\section{A. Lack of State Concept, National Consciousness and Senses of Social Responsibility}

Pressure in employment and interests drive have caused college students to give more consideration to the interests of individuals and small groups, though they have senses of hardship, yet having no or less state concept, national consciousness and social responsibility, some social bad phenomena such as unfair competition, disregarding moral principles in pursuit of profits, forging and selling bad products as well bribery have caused server impacts on the world outlook, outlook on life and values of the students whose thoughts are not shaped, and money worship, venality and hedonism have become the life motto of some students, 
and the negativity and decadence have become the spiritual world of them.

\section{B. Lowered Degree of Recognition to the Culture and Politics in the Country}

Due to the pressure in enrollment, and the education of excellent traditional culture and history in most schools are done in form but not deeply. On the other hand, some developed countries make full use the advantages of science and technologies as well as the strong position in the process of economic globalization to carry out cultural expansion and infiltration, which consequently lower the students' degree of recognition in China's culture and politics, showing confusion to socialism, they are patriotic but dislike socialism, showing indifference and even rejection against the political ideology of our country, and even posting extreme political comments, criticizing our political systems.

\section{Patriotic but Unsteady, Lack of Rational Support}

College students are an important part among contemporary youth groups, who are active in thought, enthusiastic, knowing about social phenomena, and willing to participate and think actively. However, their spontaneous and excited patriotic enthusiasm is in the lack of rational understanding, which is easy to become indifferent after excessive enthusiasm. The patriotic feeling and behavior are short-term, volatile and targeted. They have to rational understanding of patriotism, failing to convert it into a pursuit of value of their own, so the patriotic enthusiasm is difficult to convert into reasonable actions, resulting into the separation of patriotic ideals from patriotic practice, getting confused between patriotism in concept and failure in action for patriotism, and they even are rude and do something damaging the benefits of the nation and the collectives.

\section{CONCLUSION}

We believe every student has motherland at hear. Marx said: "Be a person determining and realistic, you must be required, taking missions and tasks, it matters nothing whether you know it or not, and you take the mission because of the need and your connection with the real world". Therefore, in the face of globalization today, what we have to do is to help students set and establish awareness of mission and nation, who shall be diligent, good and happy to learn, master skills, carry out the spirits of practice and devotion, practice and make the patriotism go in routine life.

\section{REFERENCES}

[1] Ye Fan, et al, Theory and Practice for Protection and Instruction of Patristic Enthusiasm of Contemporary Students [M]

[2] Ye Fan, et al, Theory and Practice for Protection and Instruction of Patristic Enthusiasm of Contemporary Students [M]

[3] Wu Qiantao, Yang Junling, Discussion on Lenin's Patriotism Thought [J] Studies on Marxism, 2010 (7). P90-96.

[4] Qian Kewei, Discussion on Lenin's Concept of Patriotism [J] Theory Monthly, 2007 (1) P16-19.
[5] Lenin, The Collected Works of Lenin, Chinese Version, Vol. 35, Rare Confession of Pitirim A Sorokin[M] Beijing: People's Publishing House, 1977. P187.

[6] Lenin, the Collected Works of Lenin, Vol. 3 [M] Beijing: People's Publishing House, 1995.P114

[7] Deng Xiaoping, Selected Works of Deng Xiaoping, Ver. 2, [M] Beijing: People's Publishing House, 1994. P392 